\title{
Village Fund Allocation Management in Kapala Pitu District, North Toraja Regency
}

\author{
Risma Niswaty* \\ Postdoctoral Program, Universitas \\ Negeri Makassar \\ E-mail: risma.niswaty@unm.ac.id
}

\author{
Andi Cudai Nur \\ Postdoctoral Program, Universitas \\ Negeri Makassar \\ E-mail: cudainur@gmail.com
}

\author{
Hasni \\ Faculty of Social Science, Universitas \\ Negeri Makassar \\ E-mail: hasni@unm.ac.id \\ Diaz Rency Sesa \\ Postdoctoral Program, Universitas \\ Negeri Makassar \\ E-mail: diazrency96@gmail.com
}

\begin{abstract}
Management is an activity carried out by moving people or workers to do a job. Allocation of village funds is part of village finances obtained from regional tax revenue sharing and part of the central and regional financial balancing funds received by districts for villages at least $10 \%$ (ten percent). All activities originating from the village fund allocation budget are planned, implemented and evaluated openly by involving all village communities. Administrative accountability in North Toraja district is in the good category. The village, the implementing team or the supervisors carry out their respective duties properly according to administrative procedures. The management of infrastructure for village fund allocation in North Toraja Regency is in the good category. In managing the allocation of village funds in North Toraja, professionalism, effectiveness, and efficiency in administrative activities are good because they are done well according to existing procedures. There is a relationship between administrative accountability and the management of village fund allocation infrastructure in North Toraja Regency. It is known that administrative accountability in the management of village fund allocations has a correlation value of 0.670 from the person correlation sig (1-tailed) value associated with each variable, which means that there is a relationship between variables $\mathrm{X}$ and $\mathrm{Y}$.
\end{abstract}

\section{Keywords - Competency Model, Village Fund Allocation, administrative accountability}

\section{INTRODUCTION}

The village as a government that directly contacts the community is the main focus in government development, this is because most of Indonesia's territory is in rural areas. In the Village Fund Pocket Book (2017), Village Funds are APBN funds allocated for Villages that are transferred through the Regency / City APBD and prioritized for the implementation of development and empowerment of Village communities. Government Regulation of the Republic of Indonesia Number 22 of 2015 concerning Amendments to Government Regulation Number 60 of 2014 concerning Village Funds sourced from the State Revenue and Expenditure Budget in the Official Guidelines for Village Fund Implementation Guidelines (2016), in Chapter 1 General Provisions Article 1 paragraph 2, Fund Villages are funds sourced from the State Revenue and
Expenditure Budget allocated to Villages which are transferred through the Regency / City Regional Revenue and Expenditure Budget and used to finance governance, development implementation, community development and community empowerment [1].

The Village Fund Allocation is a fund that is significant enough for the Village to support Village programs. Financial management, from budget to realization, must involve community leaders and local government officials, both the Village Government and the District Government. The obstacle faced by governments in allocating village funds is the lack of control over the management of village funds. Therefore it is necessary to know the extent to which the effectiveness of the management of the Village Fund Allocation in the village program so that the goals of the Government can be realized [2], [3].

The village fund allocation policy that has been implemented has a big goal which is more or less the same, namely to overhaul the orthodoxy of the district government in providing authority, services and financial assistance to the government at lower levels (villages) [4]. The district government policy pattern that was originally dominant and centralist, through the village fund allocation method, has changed to become participatory, responsive, and implemented through the principle of decentralization.

Permendagri No.113 of 2014 states that village financial management is all activities that include planning, administration, reporting, and village financial accountability. Village financial management is a series of cycles that are integrated and integrated from one stage to another.

Village finances are managed based on transparent, accountable, participatory principles, and are carried out in an orderly and disciplined budget. The series and principles of village financial management must be implemented and fulfilled by every village so that governance, implementation of village development, village community development, and 
village community empowerment can go according to plan, so that the vision of a prosperous village and community can be realized [5].

The cycle of village financial management will not run without good village governance. Therefore, the participation of parties outside the village government and the Village Consultative Body (BPD), such as village leaders, religious leaders, representatives of women, representatives of farmers, representatives of the poor and others need to be involved in the financial management process. village. Village financial accountability is not only horizontal between the village government and the Village Deliberative Council (BPD), but must also be vertical between the village head and the village community and the superior of the village head. Public documents on village financial management must be accessible to village communities, and not discriminate against certain groups related to village financial management [6], [7].

Most organizations use or are developing competency models to select, evaluate, and develop their managers based on the behavioral characteristics and traits desired in the best performing organizational leaders. Such models may be ineffective if they do not include procedures that reflect the validity of their standard of behavior. Models that are not validated will not describe managers who will be effective in achieving organizational goals [8]-[10]. The models must also include and reflect the validity of behavioral characteristics that indicate attitudes, goals and underlying characteristics, and the ways in which these characteristics can be obtained. An effective competency model must also allow for changing conditions in the future.

The competency model is not just a series of hopes or desires. Rather, it must involve a methodology that demonstrates the standard validity of the model. Competency models must also identify and validate behaviors that imply underlying motives, traits and attitudes. Another problem is that managers are often developed with respect to current competency models only, not futureoriented [11].

Competence is the behavior that distinguishes effective and ineffective managers or leaders. Certain motives, traits, skills and abilities are associated with people consistently behaving in certain ways. The competency model describes motives, traits, and so on as a set of desired behaviors for a certain position or level of work [12]-[14]. In managing the Village Fund Allocation, the village head as activity manager of course has limitations in implementing various projects in his working area. Various competencies are needed to carry out the responsibilities of developing the village in a professional manner.

\section{METHODOLOGY}

In order for the data obtained by the questionnaire to be valid and reliable, it is necessary to test the validity and reliability of the questionnaire on the questions so that it can be seen whether it is appropriate for collection.

Percentage analysis was carried out on parameters by adopting the categories proposed by Arikunto (1998: 65) as follows: $86 \%-100 \%$ categorized as very good, $71 \%-85 \%$ categorized as good, $56 \%-70 \%$ categorized as quite good, $40 \%-50 \%$ categorized as not good and less than $40 \%$ categorized as very bad.

\section{RESULT AND DISCUSSION}

A. Effectiveness of Financial Management for Village Fund Allocation in North Toraja Regency

[15] states that management can be defined as management, management is a process that is applied by individuals or groups in coordination efforts to achieve a goal. [16] states that village financial management is all activities that include planning, administration, reporting, and village financial accountability. Village financial management is a series of cycles that are integrated and integrated between one stage and another.

[17], [18] states that Village finances are managed based on transparent, accountable, participatory principles and are carried out in an orderly and disciplined budget. The series and principles of village financial management must be implemented and fulfilled by every village so that governance, implementation of village development, village community development, and village community empowerment can go according to plan, so that the vision of a village and a prosperous community can be realized.

The cycle of village financial management will not run without good village governance. Therefore, the participation of parties outside the village government and the Village Consultative Body (BPD), such as village leaders, religious leaders, representatives of women representatives from farmers, representatives from the poor and others need to be involved in the process of village financial management.

Village financial management is described in detail in (Regulation of the Minister of Home Affairs of the Republic of Indonesia Number 113 of 2014 concerning Village Financial Management, 2014) Chapter V Management of Part One concerning planning. 
Figure 1: Financial Management Cycle

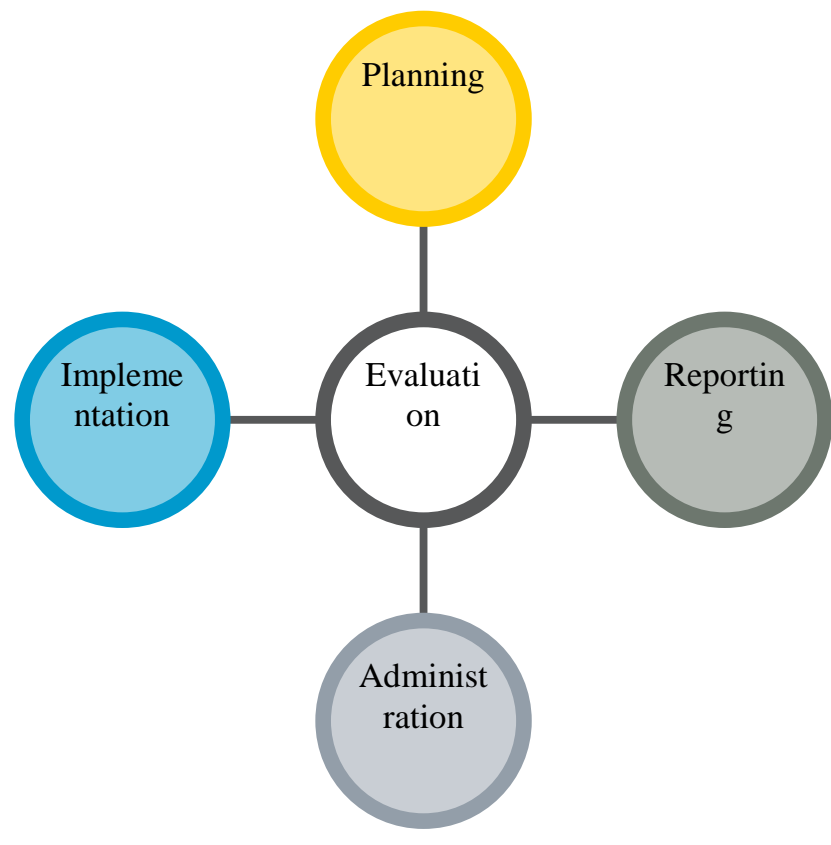

Source: (Regulation of the Minister of Home

Affairs of the Republic of Indonesia Number 113 of 2014 concerning Village Financial Management, 2014)

To test the hypothesis that has been made by previous researchers, quantitative research methods are used using statistical formulas and computer software with the Statistical Predict Standard Solution (SPSS) process which is considered relevant for analyzing data or answers from respondents with the aim of knowing how the influence between the three variables that has been researched. The research results obtained are presented as follows:

1) Validity Test Results

In this study, to see the validity of the statement items that have been made, the Corrected Item Total Correlation analysis is used with SPSS. 21. is done by looking at the numbers located in the "Corrected Item Total Correlation" column. If the questionnaire in the column is greater than the r-table value then the question item is valid, the r-table value is sought at the $5 \%$ or 0.05 significance level with the number $(n)=120$, then an $r$-table is obtained of 0.176 . If the Corrected Item Total Correlation value is greater than the rtable value then it is declared valid and vice versa if the Corrected Item Total Correlation value is greater than the $r$ table value then it is declared valid and vice versa if the Corrected Item Total Correlation value is smaller than the $r$ table value then will be declared invalid. Following are the results of the calculation of SPSS.21 statement items from Variable X (Administrative Accountability), namely:
Table 1. Item Total Statistics Variable X

(Administrative Accountability)

\begin{tabular}{|c|c|c|c|}
\hline No. Item & $\begin{array}{l}\text { Corrected Item } \\
\text { Total Correlion }\end{array}$ & $\begin{array}{l}\text { Nilai } r- \\
\text { tabel }\end{array}$ & Ket. \\
\hline 1 & $496^{* *}$ & 0.176 & Valid \\
\hline 2 & $.257^{* *}$ & 0.176 & Valid \\
\hline 3 & $.325^{* *}$ & 0.176 & Valid \\
\hline 4 & $.872^{* * *}$ & 0.176 & Valid \\
\hline 5 & $.313^{* *}$ & 0.176 & Valid \\
\hline 6 & $.613^{* *}$ & 0.176 & Valid \\
\hline 7 & $.337^{* *}$ & 0.176 & Valid \\
\hline 8 & $.400^{* *}$ & 0.176 & Valid \\
\hline 9 & $.496^{* *}$ & 0.176 & Valid \\
\hline 10 &. $\mathbf{4 5 3}^{* *}$ & 0.176 & Valid \\
\hline 11 & $.780^{* *}$ & 0.176 & Valid \\
\hline 12 & .875 & 0.176 & Valid \\
\hline 13 & $.587^{* *}$ & 0.176 & Valid \\
\hline 14 & $.898^{* *}$ & 0.176 & Valid \\
\hline 15 & $.257^{* *}$ & 0.176 & Valid \\
\hline 16 & $.834^{* *}$ & 0.176 & Valid \\
\hline 17 & $.890 * *$ & 0.176 & Valid \\
\hline 18 & $.520 * *$ & 0.176 & Valid \\
\hline 19 & $.451 * *$ & 0.176 & Valid \\
\hline 20 & $.872 * *$ & 0.176 & Valid \\
\hline
\end{tabular}

Based on the column "Corrected Item Total Correlation" in table 4.1 above, it can be seen that all question items are greater than the r-table value of 0.176 , thus it can be concluded that all question items on variable $\mathrm{X}$ (Administrative Accountability) are declared valid and fit for use.

B) Percentage Result of Village Fund Allocation Management

Table 2. Achievement Levels of Village Fund Allocation Variable Score (Y) in Angin-Angin Village

\begin{tabular}{|l|l|l|l|l|l|}
\hline $\begin{array}{l}\text { Alloca } \\
\text { tion of } \\
\text { village } \\
\text { funds }\end{array}$ & $\begin{array}{l}\text { Numb of } \\
\text { er of } \\
\text { Questi } \\
\text { on } \\
\text { Items }\end{array}$ & $\begin{array}{l}\text { Score } \\
\text { Achie } \\
\text { ved }\end{array}$ & $\begin{array}{l}\text { Ideal } \\
\text { Score }\end{array}$ & $\begin{array}{l}\text { Achie } \\
\text { vemen } \\
\text { t (\%) }\end{array}$ & $\begin{array}{l}\text { Categ } \\
\text { ory }\end{array}$ \\
\hline Planni & 5 & 500 & 500 & 100 & Very \\
\hline
\end{tabular}




\begin{tabular}{|l|l|l|l|l|l|}
\hline ng & & & & & \\
\hline $\begin{array}{l}\text { Imple } \\
\text { menta } \\
\text { tion }\end{array}$ & 5 & 500 & 500 & 100 & $\begin{array}{l}\text { Very } \\
\text { good }\end{array}$ \\
\hline $\begin{array}{l}\text { Admi } \\
\text { nistrat } \\
\text { ion }\end{array}$ & 5 & 462 & 500 & 92,4 & $\begin{array}{l}\text { Very } \\
\text { good }\end{array}$ \\
\hline $\begin{array}{l}\text { Repor } \\
\text { ting }\end{array}$ & 5 & 480 & 500 & 96 & $\begin{array}{l}\text { Very } \\
\text { good }\end{array}$ \\
\hline $\begin{array}{l}\text { Accou } \\
\text { ntabili } \\
\text { ty }\end{array}$ & 5 & 500 & 500 & 100 & $\begin{array}{l}\text { Very } \\
\text { good }\end{array}$ \\
\hline Total & $\mathbf{2 5}$ & $\mathbf{2 2 4 4 2}$ & $\mathbf{2 5 0 0}$ & $\mathbf{9 7 , 6 8}$ & $\begin{array}{l}\text { Very } \\
\text { good }\end{array}$ \\
\hline
\end{tabular}

Based on Table 2 above, it can be seen that the percentage achievement level for the village fund allocation variable in the village of Angin-Angin is in the very good category with a percentage figure $(97.68 \%)$.

Table 3. Level of Achievement of Village Fund Allocation Variable Score (Y) in Rinding Batu Village

\begin{tabular}{|l|l|l|l|l|l|}
\hline $\begin{array}{l}\text { Alloca } \\
\text { tion of } \\
\text { village } \\
\text { funds }\end{array}$ & $\begin{array}{l}\text { Numb } \\
\text { er of } \\
\text { Questi } \\
\text { on } \\
\text { Items }\end{array}$ & $\begin{array}{l}\text { Score } \\
\text { Achie } \\
\text { ved }\end{array}$ & $\begin{array}{l}\text { Ideal } \\
\text { Score }\end{array}$ & $\begin{array}{l}\text { Achie } \\
\text { vemen } \\
\mathbf{t}(\mathbf{\%})\end{array}$ & $\begin{array}{l}\text { Categ } \\
\text { ory }\end{array}$ \\
\hline $\begin{array}{l}\text { Planni } \\
\text { ng }\end{array}$ & 5 & 498 & 500 & 99,6 & $\begin{array}{l}\text { Very } \\
\text { good }\end{array}$ \\
\hline $\begin{array}{l}\text { Imple } \\
\text { menta } \\
\text { tion }\end{array}$ & 5 & 500 & 500 & 100 & $\begin{array}{l}\text { Very } \\
\text { good }\end{array}$ \\
\hline $\begin{array}{l}\text { Admi } \\
\text { nistrat } \\
\text { ion }\end{array}$ & 5 & 464 & 500 & 92,8 & $\begin{array}{l}\text { Very } \\
\text { good }\end{array}$ \\
\hline $\begin{array}{l}\text { Repor } \\
\text { ting }\end{array}$ & 5 & 473 & 500 & 94,6 & $\begin{array}{l}\text { Very } \\
\text { good }\end{array}$ \\
\hline $\begin{array}{l}\text { Accou } \\
\text { ntabili } \\
\text { ty }\end{array}$ & 5 & 452 & 500 & 90,4 & $\begin{array}{l}\text { Very } \\
\text { good }\end{array}$ \\
\hline Total & $\mathbf{2 5}$ & $\mathbf{2 3 8 7}$ & $\mathbf{2 5 0 0}$ & $\mathbf{8 9 , 4 8}$ & $\begin{array}{l}\text { Very } \\
\text { good }\end{array}$ \\
\hline
\end{tabular}

Based on table 3 above, it can be seen that the percentage achievement level for the village fund allocation variable in Rinding Batu village is in the very good category with a percentage figure $(89.48 \%)$

Table 4. Level of Achievement of Village Fund Allocation Variable Score (Y) in North Baruppu Village

\begin{tabular}{|l|l|l|l|l|l|}
\hline $\begin{array}{l}\text { Alloca } \\
\text { tion of } \\
\text { village } \\
\text { funds }\end{array}$ & $\begin{array}{l}\text { Numb or of } \\
\text { Questi } \\
\text { on } \\
\text { Items }\end{array}$ & $\begin{array}{l}\text { Score } \\
\text { Achie } \\
\text { ved }\end{array}$ & $\begin{array}{l}\text { Ideal } \\
\text { Score }\end{array}$ & $\begin{array}{l}\text { Achie } \\
\text { vemen } \\
\mathbf{t}(\%)\end{array}$ & $\begin{array}{l}\text { Categ } \\
\text { ory }\end{array}$ \\
\hline Planni & 5 & 472 & 500 & 94,4 & Very \\
\hline
\end{tabular}

\begin{tabular}{|l|l|l|l|l|l|}
\hline ng & & & & & good \\
\hline $\begin{array}{l}\text { Imple } \\
\text { menta } \\
\text { tion }\end{array}$ & 5 & 493 & 500 & 98,6 & $\begin{array}{l}\text { Very } \\
\text { good }\end{array}$ \\
\hline $\begin{array}{l}\text { Admi } \\
\text { nistrat } \\
\text { ion }\end{array}$ & 5 & 472 & 500 & 94,4 & $\begin{array}{l}\text { Very } \\
\text { good }\end{array}$ \\
\hline $\begin{array}{l}\text { Repor } \\
\text { ting }\end{array}$ & 5 & 468 & 500 & 93,6 & $\begin{array}{c}\text { Very } \\
\text { good }\end{array}$ \\
\hline $\begin{array}{l}\text { Accou } \\
\text { ntabili } \\
\text { ty }\end{array}$ & 5 & 328 & 500 & 65,6 & $\begin{array}{c}\text { Pretty } \\
\text { good }\end{array}$ \\
\hline Total & $\mathbf{2 5}$ & $\mathbf{2 2 3 3}$ & $\mathbf{2 5 0 0}$ & $\mathbf{8 9 , 3 2}$ & $\begin{array}{c}\text { Very } \\
\text { good }\end{array}$ \\
\hline
\end{tabular}

Based on table 4 above, it can be seen that the percentage achievement level for the village fund allocation variable in the North Baruppu village is in the very good category with a percentage figure (89.32).

Table 5. Level of Achievement of Village Fund Allocation Variable Score (Y) in Baruppu Parodo Village

\begin{tabular}{|l|l|l|l|l|l|}
\hline $\begin{array}{l}\text { Alloca } \\
\text { tion of } \\
\text { village } \\
\text { funds }\end{array}$ & $\begin{array}{l}\text { Numb of } \\
\text { er } \\
\text { Questi } \\
\text { on } \\
\text { Items }\end{array}$ & $\begin{array}{l}\text { Score } \\
\text { Achie } \\
\text { ved }\end{array}$ & $\begin{array}{l}\text { Ideal } \\
\text { Score }\end{array}$ & $\begin{array}{l}\text { Achie } \\
\text { vemen } \\
\mathbf{t}(\%)\end{array}$ & $\begin{array}{l}\text { Categ } \\
\text { ory }\end{array}$ \\
\hline $\begin{array}{l}\text { Planni } \\
\text { ng }\end{array}$ & 5 & 464 & 500 & 92,8 & $\begin{array}{l}\text { Very } \\
\text { good }\end{array}$ \\
\hline $\begin{array}{l}\text { Imple } \\
\text { menta } \\
\text { tion }\end{array}$ & 5 & 497 & 500 & 99,4 & $\begin{array}{l}\text { Very } \\
\text { good }\end{array}$ \\
\hline $\begin{array}{l}\text { Admi } \\
\text { nistrat } \\
\text { ion }\end{array}$ & 5 & 475 & 500 & 95 & $\begin{array}{l}\text { Very } \\
\text { good }\end{array}$ \\
\hline $\begin{array}{l}\text { Repor } \\
\text { ting }\end{array}$ & 5 & 457 & 500 & 91,4 & $\begin{array}{l}\text { Very } \\
\text { good }\end{array}$ \\
\hline $\begin{array}{l}\text { Accou } \\
\text { ntabili } \\
\text { ty }\end{array}$ & 5 & 435 & 500 & 87 & $\begin{array}{l}\text { Very } \\
\text { good }\end{array}$ \\
\hline Total & $\mathbf{2 5}$ & $\mathbf{2 3 2 8}$ & $\mathbf{2 5 0 0}$ & $\mathbf{9 3 , 1 2}$ & $\begin{array}{l}\text { Very } \\
\text { good }\end{array}$ \\
\hline
\end{tabular}

Based on table 5 above, it can be seen that the percentage achievement level for the village fund allocation variable in the Baruppu Parodo Village is in the very good category with a percentage figure $(93.12 \%)$.

Table 6. Level of Achievement of Village Fund Allocation Variable Score (Y) in Benteng Ka'do Village

\begin{tabular}{|l|l|l|l|l|l|}
\hline $\begin{array}{l}\text { Alloca } \\
\text { tion of } \\
\text { village } \\
\text { funds }\end{array}$ & $\begin{array}{l}\text { Numb } \\
\text { er of } \\
\text { Questi } \\
\text { on } \\
\text { Items }\end{array}$ & $\begin{array}{l}\text { Score } \\
\text { Achie } \\
\text { ved }\end{array}$ & $\begin{array}{l}\text { Ideal } \\
\text { Score }\end{array}$ & $\begin{array}{l}\text { Achie } \\
\text { vemen } \\
\text { t }(\%)\end{array}$ & $\begin{array}{l}\text { Categ } \\
\text { ory }\end{array}$ \\
& & & \\
\hline
\end{tabular}




\begin{tabular}{|l|l|l|l|l|l|}
\hline $\begin{array}{l}\text { Planni } \\
\text { ng }\end{array}$ & 5 & 478 & 500 & 95,6 & $\begin{array}{l}\text { Very } \\
\text { good }\end{array}$ \\
\hline $\begin{array}{l}\text { Imple } \\
\text { menta } \\
\text { tion }\end{array}$ & 5 & 497 & 500 & 99,4 & $\begin{array}{l}\text { Very } \\
\text { good }\end{array}$ \\
\hline $\begin{array}{l}\text { Admi } \\
\text { nistrat } \\
\text { ion }\end{array}$ & 5 & 461 & 500 & 92,2 & $\begin{array}{c}\text { Very } \\
\text { good }\end{array}$ \\
\hline $\begin{array}{l}\text { Repor } \\
\text { ting }\end{array}$ & 5 & 437 & 500 & 87,4 & $\begin{array}{l}\text { Very } \\
\text { good }\end{array}$ \\
\hline $\begin{array}{l}\text { Accou } \\
\text { ntabili } \\
\text { ty }\end{array}$ & 5 & 326 & 500 & 65,2 & $\begin{array}{c}\text { Pretty } \\
\text { good }\end{array}$ \\
\hline Total & $\mathbf{2 5}$ & $\mathbf{2 2 3 5}$ & $\mathbf{2 5 0 0}$ & $\mathbf{8 7 , 9 6}$ & $\begin{array}{l}\text { Very } \\
\text { good }\end{array}$ \\
\hline
\end{tabular}

Based on table 6 above, it can be seen that the percentage achievement level for the Administrative Accountability variable in Baruppu Ka'do Village is in the very good category with a percentage figure $(87.96 \%)$.

Table 7. Level of Achievement of Village Fund Allocation Variable Score (Y) in Benteng Mamullu Village

\begin{tabular}{|l|l|l|l|l|l|}
\hline $\begin{array}{l}\text { Alloca } \\
\text { tion of } \\
\text { village } \\
\text { funds }\end{array}$ & $\begin{array}{l}\text { Numb } \\
\text { er of } \\
\text { Questi } \\
\text { on } \\
\text { Items }\end{array}$ & $\begin{array}{l}\text { Score } \\
\text { Achie } \\
\text { ved }\end{array}$ & $\begin{array}{l}\text { Ideal } \\
\text { Score }\end{array}$ & $\begin{array}{l}\text { Achie } \\
\text { vemen } \\
\mathbf{t}(\mathbf{\%})\end{array}$ & $\begin{array}{l}\text { Categ } \\
\text { ory }\end{array}$ \\
\hline $\begin{array}{l}\text { Planni } \\
\text { ng }\end{array}$ & 5 & 487 & 500 & 97,4 & $\begin{array}{l}\text { Very } \\
\text { good }\end{array}$ \\
\hline $\begin{array}{l}\text { Imple } \\
\text { menta } \\
\text { tion }\end{array}$ & 5 & 490 & 500 & 98 & $\begin{array}{l}\text { Very } \\
\text { good }\end{array}$ \\
\hline $\begin{array}{l}\text { Admi } \\
\text { nistrat } \\
\text { ion }\end{array}$ & 5 & 430 & 500 & 86 & $\begin{array}{l}\text { Very } \\
\text { good }\end{array}$ \\
\hline $\begin{array}{l}\text { Repor } \\
\text { ting }\end{array}$ & 5 & 334 & 500 & 66,8 & $\begin{array}{l}\text { Pretty } \\
\text { good }\end{array}$ \\
\hline $\begin{array}{l}\text { Accou } \\
\text { ntabili } \\
\text { ty }\end{array}$ & 5 & 367 & 500 & 73,4 & Good \\
\hline Total & $\mathbf{2 5}$ & $\mathbf{2 1 0 8}$ & $\mathbf{2 5 0 0}$ & $\mathbf{8 4 , 3 2}$ & $\begin{array}{l}\text { Very } \\
\text { good }\end{array}$ \\
\hline
\end{tabular}

Based on table 7 above, it can be seen that the percentage achievement level for the village fund allocation variable in Benteng Mamullu Village is in the good category with a percentage figure $(84.32 \%)$.

\section{CONCLUSION}

Management of Village Fund Allocation in Kapala Pitu District, North Toraja Regency shows:

1. Administrative accountability in Toraja district is in the good category. The village, the implementing team or the supervisors carry out their respective duties properly according to administrative procedures.

2. The management of village fund allocation infrastructure in North Toraja Regency is in the good category. In managing the allocation of village funds in North Toraja, professionalism, effectiveness, and efficiency in administrative activities are good because they are done well according to existing procedures

3. There is a relationship between administrative accountability and the management of village fund allocation infrastructure in North Toraja Regency. It is known that administrative accountability in the management of village fund allocations has a correlation value of 0.670 from the person correlation sig (1-tailed) value associated with each variable, which means that there is a relationship between variables $\mathrm{X}$ and $\mathrm{Y}$.

\section{Acknowledgment}

This research was funded by the 2020 Masters Thesis Research, with contract number $165 / \mathrm{UN} 36.11 / \mathrm{LP} 2 \mathrm{M} / 2020$. Thank you to Kemenristekdikti, Rector of UNM, Chair of LP2M, and Director of Postgraduate Program at Makassar State University.

\section{REFERENCES}

[1] Peraturan Menteri Dalam Negeri, Peraturan Menteri Dalam Negeri Republik Indonesia Nomor 113 Tahun 2014 tentang Pengelolaan Keuangan Desa. 2014, pp. 1-16.

[2] R Fajri, "Akuntabilitas Pemerintah Desa pada Pengelolaan Alokasi Dana Desa (Studi Pada Kantor Desa Ketindan, Kecamatan Lawang, Kabupaten Malang)," Adm. ..., 2015.

[3] N. A. Bahtiar, "Partisipasi Masyarakat Dalam Pengawasan Program Alokasi Dana Desa ( Add ) Di Desa Panjunan Kecamatan Sukodono Kabupaten Sidoarjo," Kebijak. dan Manaj. Publik, 2017, doi: 2303-341X.

[4] putu andi suarjaya Putra and kadekmade ari Sinarwati, "Akuntabilitas dan Transparansi Pengelolaan Alokasi Dana Desa (ADD) di Desa Bubunan, Kecamatan Seririt, Kabupaten Buleleng," JIMAT (Jurnal Ilm. Mhs. Akuntansi) Undiksha, 2017.

[5] N. A. S. D. Ni Kadek Darmiasih, Ni Luh Gd Erni Sulindawati, "Analisis Mekanisme Penyaluran Alokasi Dana Desa (ADD) pada Pemerintah Desa (Studi Kasus Desa Tri Buana, Kec.Sidemen, Kab.Karangasem)," e-journal S1 Ak Univ. Pendidik. Ganesha Jur. Akunt. Progr. S1, 2015.

[6] S. Meskendahl, "The influence of business strategy on project portfolio management and its success - A conceptual framework," Int. J. Proj. Manag., 2010, doi: 10.1016/j.ijproman.2010.06.007.

[7] Project Management Institute, "Requirements 
Management: A Core Competency for Project and Program Success," PMI's Pulse Prof., 2014.

[8] R. Müller and R. Turner, "Leadership competency profiles of successful project managers," Int. J. Proj. Manag., 2010, doi: 10.1016/j.ijproman.2009.09.003.

[9] P. Trivellas and C. Drimoussis, "Investigating Leadership Styles, Behavioural and Managerial Competency Profiles of Successful Project Managers in Greece," Procedia - Soc. Behav. Sci., 2013, doi: 10.1016/j.sbspro.2013.02.107.

[10] H. Y. Seputro, S. D. Wahyuningsih, and S. Sunrowiyati, "Potensi Fraud Dan Strategi Anti Fraud Pengelolaan Keuangan Desa," J. Penelit. Teor. Terap. Akunt., 2017.

[11] S. M. Takey and M. M. de Carvalho, "Competency mapping in project management: An action research study in an engineering company," Int. J. Proj. Manag., 2015, doi: 10.1016/j.ijproman.2014.10.013.

[12] N. Madter, D. A. Bower, and B. Aritua, "Projects and personalities: A framework for individualising project management career development in the construction industry," Int. J. Proj. Manag., 2012, doi: 10.1016/j.ijproman.2011.09.001.

[13] M. Young and K. Conboy, "Contemporary project portfolio management: Reflections on the development of an Australian competency standard for project portfolio management," Int. J. Proj. Manag., 2013, doi: 10.1016/j.ijproman.2013.03.005.

[14] J. Y. C. Liu, H. H. G. Chen, J. J. Jiang, and G. Klein, "Task completion competency and project management performance: The influence of control and user contribution," Int. J. Proj. Manag., 2010, doi: 10.1016/j.ijproman.2009.05.006.

[15] R. M. Sari, "Akuntabilitas Pemerintahan Desa Dalam Pengelolaan Dana Desa Di Kecamatan Ngantru Kabupaten Tulungagung," J. Penelit. Teor. Terap. Akunt., 2019.

[16] J. Irianto, "Manajemen Sumber Daya Manusia Sektor Publik di Indonesia: Pengantar Pengembangan Model MSDM Sektor Publik," J. Kebijak. dan Adm. Publik, 2011.

[17] L. N. Nafidah and N. Anisa, "Akuntabilitas Pengelolaan Keuangan Desa di Kabupaten Jombang," Akuntabilitas, 2017, doi: 10.15408/akt.v10i2.5936.

[18] E. A. Ash-shidiqq and H. Wibisono, "Akuntabilitas Pengelolaan Dana Desa Sebagai Upaya Pencegahan Korupsi Pengelolaan Dana Desa," J. Huk. Unes, 2018. 